\title{
Why the Model Penal Code's Sexual Offense Provisions Should Be Pulled and Replaced
}

\author{
Deborah W. Denno*
}

\section{INTRODUCTION}

By all accounts, the Model Penal Code is enormously respected and influential. ${ }^{1}$ Yet, relatively soon after the Code's 1962 publication, the Code's sexual offense provisions and even its 1980 revised Commentaries ${ }^{2}$ were already considered outdated. The rapid onslaught of the sexual and feminist revolutions of the 1960s and $1970 \mathrm{~s}^{3}$ brought an intense momentum to change rape laws that the Code had, in part, either mirrored or inspired. ${ }^{4}$ Only because of the passage of time, the Code's sexual offense provisions and Commentaries now misrepresent the progressive thinking of the Code's reporters. For these reasons, I think the Model Penal Code's sexual offense provisions should be pulled, revised, and replaced.

With such a recommendation in mind, this essay has two goals: it explains why a number of the Code's sexual offense provisions were so advanced when they were created, but also why their continuing, unaltered existence makes their original virtues too easy to forget. What started as a leading authority for the legal enhancement of women and homosexuals is now a relic that detracts from the credit and foresight that its creators deserve. ${ }^{5}$ Periodically, the Code's Commentaries acknowledged that the

- Professor of Law, Fordham University School of Law. I thank Lawrence Fleischer, Christopher Hale, and Marc Spindleman for helpful comments and Janice Greer and Marianna Politzer for excellent research assistance.

1 Gerard E. Lynch, Revising the Model Penal Code: Keeping It Real, I OHIо ST. J. CRIM. L. 219 , 220 (2003)

2 Model PeNal CODE art. 213, introductory n. (Official Draft and Revised Comments 1980) [hereinafter MODEL PENAL CODE 1980]. There are seven sexual offense provisions in Article 213 of the Model Penal Code: $\S 213.0$ Definitions; $\S 213.1$ Rape and related offenses; $\S 213.2$ Deviate sexual intercourse by force or imposition; $\$ 213.3$ Corruption of minors and seduction; $\S 213.4$ Sexual assault; $\S 213.5$ Indecent exposure; and $\S 213.6$ Provisions generally applicable to 213 . Id. Rape, deviate sexual intercourse, and some sections of corruption of minors are felony offenses; the remaining offenses are misdemeanors. MODEL PENAL CODE 1980, supra, art. 213, introductory n. at 271-73. This essay primarily focuses on rape and related offenses. See MODEL PENAL CODE 1980, supra, §213.1 at 274.

3 See generally David Allyn, Make love, Not War: The Sexual Revolution, AN UNFETTERED HISTORY (2000) (providing a detailed analysis of the sexual revolution in the United States during the 1960 s and 1970s).

4 See Leigh Bienen, Rape III-National Developments in Rape Reform Legislation, 6 WoMEN's RTS. L. REP. 171, 175-76 (1980).

5 Others in this issue have keenly observed ways that the Code can be improved. See Lynch, supra note 1, at 227-39; Paul H. Robinson \& Michael T. Cahill, Can A Model Penal Code Second Save the States From Themselves?, 1 OHIO ST. J. CRIM. L. 169, 173-77 (2003); Kenneth W. Simons, Should the 
sexual offense provisions would at some point need redrafting to keep pace with the times. For these reasons, a primary source of support for my pull-and-replace recommendations are the contents of the Commentaries themselves.

\section{THE CODE'S COMMENTARIES: A RICH, INTERPRETATIVE GUIDE}

The Code's sexual offense provisions and their Commentaries may be dated, but they have not been displaced. Modern courts still regularly cite to them, ${ }^{6}$ and so do leading criminal law casebooks. ${ }^{7}$ The provisions also remain the American Law Institute's official word on the topic of sex offenses. ${ }^{8}$

The Commentaries in particular provide key guidance to jurists and others about how to interpret the Code's provisions. Richly detailed, the Commentaries also offer a superb analysis of the social norms of their era as well as a history and rationale for the Code reporters' decisions. One of the more intriguing revelations from the American Law Institute's extensive documentation of meetings and correspondence beyond even the Commentaries, for example, is the extent to which the Institute relied on the results of Alfred Kinsey's sexuality research for help with conceptualizing the provisions. ${ }^{9}$ Indeed, the Commentaries indicate that many of the factors that framed the Code's sexual offense provisions are still reflected in modern rape statutes. By understanding how rape laws were influenced in the past, we have a better idea of how they can be reshaped in the future.

In sum, the Code's sexual offense provisions and Commentaries are juridical, historical, and important. Let them also be up to date. To make a convincing case for revision, however, it's worthwhile examining more closely what the Commentaries say.

Model Penal Code's Mens Rea Provisions Be Amended?, 1 OHIO ST. J. CRIM. L. 179, 182-200 (2003). Two contributors have emphasized in particular the problematic nature of the sexual offenses provision. Lynch, supra note 1, at 230-31; Robinson \& Cahill, supra, at 169.

6 See MODEl PeNAl CODE 1980, supra note 2, $\S \S 213.0-6$; 10A U.L.A. $432-80$ (2003). As one would expect, some of the case references to the Model Penal Code are negative or critical. Yet, the fact that the Code is mentioned at all is indication that a court senses a need to address its authority.

7 See, e.g., JoshuA Dressler, CASES AND MATERIAL ON CRIMINAL LAW 407-08 (3d ed. 2003) (citing the provision and Commentaries pertaining to MODEL PENAL CODE $1980 \S 213.1$, and providing the sexual offense provisions in the Appendix); SANFORD H. KADISH \& STEPHEN J. SCHULhOFER, CRIMINAL LAW AND ITS PROCESSES: CASES AND MATERIAls 369-70 (7th ed. 2001) (citing the provision and Commentaries pertaining to MODEL PENAL CODE 1980 \& 213.1, and providing the sexual offense provisions in the Appendix).

8 I agree with Paul Robinson and Michael Cahill that the Institute is the most suitable body to make the changes in the Model Penal Code, and its imprimatur is important. Robinson \& Cahill, supra note 5, at $175-76$.

9 David Allyn, Private Acts/Public Policy: Alfred Kinsey, the American Law Institute and the Privatization of American Sexual Morality, 30 J. AM. STUD. 405, 407-28 (1996) (detailing Alfred Kinsey's influence on the Model Penal Code reporters responsible for the sexual offenses provisions); see also infra notes 43-44 (citing Kinsey's major books on sexuality). 


\section{THE CODE'S RAPE AND RELATED OFFENSES PROVISION}

Most of the controversy over the Code's sexual offense provisions concerns the section on rape and related offenses, ${ }^{10}$ which specifies three felony levels of sexual intercourse with a mentally competent and aware, adult woman. Rape is a felony of the second degree when a male "has sexual intercourse with a female not his wife... if ... he compels her to submit by force or by threat of imminent death, serious bodily injury, extreme pain or kidnapping, to be inflicted on anyone." 11 Rape is a felony of the first degree when a male has fulfilled these conditions and either "inflicts serious bodily injury upon anyone" or evidence shows "the victim was not [his] voluntary social companion ... upon the occasion of the crime and had not previously permitted him sexual liberties." 2 Sexual intercourse becomes the third degree felony of "gross sexual imposition" when a male "compels" a female not his wife "to submit by any threat that would prevent resistance by a woman of ordinary resolution."13

The Code's sexual offense provisions were to be a "model" for existing laws and therefore represent then current attitudes. Regardless, the rape provisions were still impressively forward thinking. For example, some offense elements had new terms and "the grading differentials by and large ha[d] no counterpart in prior law." 14

\section{A. "Objective Manifestations of Aggression by the Actor"}

A primary motivating force behind the Code's approach was an emphasis upon "objective manifestations of aggression by the actor,"15 an effort to focus on the defendant's actions rather than the victim's. Yet, another major concern was to protect the defendant against unfair prosecution. At the time the Code's provisions were first published, rape was still a capital offense $;{ }^{16}$ the punitive stakes were high, particularly for black men accused of raping white women. ${ }^{17}$

Irrespective of the Code's precise reasons for its approach, the Commentaries make clear that prosecutions were not tenable without objective evidence of the defendant's use of force. For example, an injury criterion for first-degree rape was considered "plainly relevant to the dangerousness of the actor and an objectively determinable event that reinforces a conclusion of aggression by the actor and

10 Model Penal Code 1980, supra note 2, § 213.1 at 274-75.

1 Id. $\S 213.1(1)$ (a) at 274.

12 Id. $\$ 213.1(1)$ at 274.

13 Id. $\$ 213.1(2)$ (a) at 275.

14 Id. $\S 213.1 \mathrm{cmt} .2$ at 279

15 Id. at 280.

16 In Coker v. Georgia, 433 U.S. 584 (1977), the United States Supreme Court held that the death penalty for the rape of an adult woman was "grossly disproportionate and excessive" and therefore prohibited as cruel and unusual punishment under the Eighth Amendment. Id. at 592.

17 Model Penal Code 1980, supra note 2, $\$ 213.1 \mathrm{cmt}$. 3 at 281-82. 
nonconsent by the victim." ${ }^{.18}$ In contrast, the voluntary social companion criterion "reduces confidence in the conclusion of aggression and nonconsent, and seems relevant as well to the degree of injury inflicted and the general dangerousness of the actor."19

Efforts to require this kind of "objective" verification and degree of injury have backfired in light of today's attitudes towards sexual force. Also, the great majority of rapes do not involve serious bodily injury beyond penetration even though most victims believe that they will be hurt or even killed.

\section{B. "Voluntary Social Companion"}

One of the more controversial facets of the Code's rape provisions is the lesser felony degree that applies when the victim was the defendant's "voluntary social companion" and had "previously permitted him sexual liberties"-ill-defined and antiquated terms that are now interpreted as a euphemism for date rape. This issue has hardly been relegated to history. In 1997, for example, United States Senator Joseph Biden lobbied Delaware legislators to eliminate the "voluntary social companion" element of his state's rape statute that treated accused rapists substantially less harshly if a victim had accompanied them willingly at the time of the alleged assault (unless the attacker used a gun or inflicted serious injury beyond the intercourse) ${ }^{20}$ Biden considered Delaware's provision "barbaric" and "obscene," because "rape is rape, no matter what the relationship." 21

The Delaware law, now since repealed, no longer uses the voluntary social companion language. ${ }^{22}$ The Code should follow suit.

\section{Male Perpetrator, Female Victim}

The Code's gender specific requirement for rape is also problematic. The Commentaries conceded, however, that a gender neutral approach "may well be ... more desirable." 23 For example, "[c]oerced vaginal intercourse by a female upon a male is not explicitly covered by any of the [sexual offense] provisions." ${ }^{24}$ Likewise, the Commentaries state forthrightly that "[i]f the Model Code were being redrafted today, it might well be that preserving these [gender] differences would not be thought to outweigh the advantages of describing the entire offense of rape in gender-neutral

18 Id. $\mathrm{cmt} .2$ at 280.

19 Id

20 Todd Spangler, Senator Takes Aim at Out-of-Date Rape Statute Still on the Books, DAlLY RECORD (Baltimore, MD), Sept. 24, 1997, at 24.

21 Id.

22 Stevens v. Delaware, 295 F.3d 361, 365 n.2 (3d Cir. 2002) (citing Del. CoDE ANN. tit. 11, § 773 (2001)).

23 Model Penal Code 1980, supra note 2, $\S 213.1 \mathrm{cmt} .3$ at 294.

24 Id. $\mathrm{cmt} .6$ at 336. 
terms." ${ }^{.25}$ Gender neutrality could also "help to abrogate certain sex stereotypes that our society is appropriately beginning to address., ${ }^{, 26}$ On other pages, however, the Commentaries oddly appear to waver on this issue; instead, they emphasize the limited number of same-sexed cases that arise and the need to confine punishment for first degree felonies to those cases "where the harm to the victim is likely to be perceived as the most severe." 27

Today, nearly all rape statutes in this country are gender neutral. ${ }^{28}$ The maleperpetrator, female-victim requirement dates the Code in light of modern attitudes and knowledge about the comparable severity of rape involving other gender combinations. ${ }^{29}$ Given the Commentaries' own recognition of this inequity, a change to gender neutrality is long overdue.

\section{THE CODE’s LITERATURE ON SEX AND RAPE}

In general, the Commentaries highlighted the most progressive views on the topics of sexuality and rape that reigned in the sixties and seventies (and that remain important today). They also referred to scholarship that is still commonly cited, such as Vivian Berger's landmark article in Columbia Law Review. ${ }^{30}$ Otherwise, however, there was very little material available for them to use. For example, nearly all of the Commentaries' references to trends in rape statutes rely on Helene Shapo's 1975 student Note in Virginia Law Review. ${ }^{31}$ While Shapo's Note is well done, it appears to be the only existing source for such information at the time, and the Commentaries, by necessity, cite to it repeatedly.

I believe the Code's reporters wrote a highly informative and sophisticated text given the cultural and societal constraints of the time. It would be unfair to judge them in hindsight by today's standards, particularly because their efforts to be forward thinking were so clear. ${ }^{32}$ Regardless, one of the more striking indicators of the dated

$25 \quad$ Id. at 337.

26 Id.

27 Id. at 338.

28 Deborah W. Denno, Sexuality, Rape, and Mental Retardation, 1997 U. ILL. L. REV. 315, 341 n.152.

29 Deborah W. Denno, Why Rape is Different, 63 FORDHAM L. REV. 125, 127-28 (1994) (discussing the severity of sexual assaults against males, which appear to be downplayed in the literature on rape).

30 Vivian Berger, Man's Trial, Woman's Tribulation: Rape Cases in the Courtroom, 77 ColuM. L. REV. 1 (1977).

31 Model Penal Code 1980, supra note 2, $\$ 213.1 \mathrm{cmt} .1$ at $278-79 \mathrm{nn} .16$ \& 24; cmt. 3 at 286 n. $42 ; \mathrm{cmt} .3$ at 299 n. $60 ; \mathrm{cmt} .4$ at $305 \mathrm{nn} .87 \& 90 ; \mathrm{cmt} .6$ at $334 \mathrm{n} .168 ; \mathrm{cmt} .6$ at $349-50 \mathrm{nn} .208 \& 211 ; \S$ $213.6 \mathrm{cmt} .6$ at $422 \mathrm{n.33}$; cmt. 6 at $425 \mathrm{n} .51$ (citing H. S. Shapo, Note, Recent Statutory Developments in the Definition of Forcible Rape, 61 VA. L. REV. 1500 (1975)).

32 For a superb overview of the literature and thinking of the $1960 \mathrm{~s}$ and $1970 \mathrm{~s}$, see generally ALLYN, supra note 3. For example, Allyn notes in particular that the American Law Institute started endorsing abortion reform in 1959 whereas the American Medical Association "objected to even limited reform efforts until 1967." Id. at 178. Indeed, renowned figures at the time considered the American 
nature of the Commentaries are the books and articles that they reference; while cutting edge and respected then, they now look, with rare exception, merely old fashioned.

For the most part, these decades-old materials are referenced in the Commentaries dealing with "deviate sexual intercourse by force or imposition.",33 There seems to be a clear agenda prompting the use of this particular literature because much of it discussed the prevalence and social acceptance of oral and anal sex and therefore favored the decriminalization of homosexuality. The literature also focused on feminist views of women's status and sexuality. Sources supporting the rights of either women or homosexuals (or both) included Ms. Magazine ${ }^{34}$ Sexology Magazine $^{35}$ (once a highly respected journal authored by renowned medical practitioners but defunct since the 1970s), Rolling Stone, ${ }^{36}$ Parents' Magazine ${ }^{37}$ and Playboy $^{38}$ (now often mocked, but at one time the source of insightful interviews with prominent officials, such as former President Jimmy Carter). ${ }^{39}$

The Commentaries also cited, with varying levels of frequency, a series of then popular and influential books: Against Our Will (1975), ${ }^{40}$ The Female Eunuch (1971), ${ }^{41}$ Sexual Politics (1970), ${ }^{42}$ Sexual Behavior in the Human Female (1953), ${ }^{43}$ Sexual Behavior in the Human Male (1st ed. 1948), ${ }^{44}$ The Joy of Sex (1972), ${ }^{45}$ Everything You Always Wanted to Know About Sex (1970), ${ }^{46}$ Sexual Harmony in

Law Institute's endorsement of abortion "the first major stimulus toward significant liberalization" of the practice. David J. GarRow, LiberTy and SEXUALITY: The Right TO PRIVACY AND THE MAKING OF RoE V. WADE 277 (1994).

33 Model Penal Code 1980, supra note 2, § 213.2.

34 Id. $\S 213.1 \mathrm{cmt} .3$ at $281 \mathrm{n} .25$.

35 Id. at 283 n.32.

36 Id. cmt. 6 at 349 n. 208 .

37 Id. $\S 213.2 \mathrm{cmt} .2$ at $363 \mathrm{n} .26$.

$38 \quad I d . ; 366 \mathrm{n} .31$.

39 See ALLYN, supra note 3, at 27 (noting that Hugh Hefner, the founder of Playboy, "included enough serious material-short stories, interviews, investigative journalism, and cultural criticism by popular writers - to make his magazine respectable in the eyes of most middle-class Americans").

40 Model Penal Code 1980, supra note 2, $\$ 213.1 \mathrm{cmt} .3$ at $281 \mathrm{n} .27$ (citing SUSAN BROWNMILLER, AGAINST OUR WILL: MEN, WOMEN, AND RAPE (1975)) (cited throughout the Commentaries).

41 Id. at 283 n.32 (citing Germaine Greer, The Female Eunuch (1971)).

$42 I$ d. at $350 \mathrm{cmt} 6 \mathrm{n} .211$ (citing Kate Millett, SeXual Politics (1970)); $\$ 213.6 \mathrm{cmt}$. 6 at 427 n.60 (same).

43 Id. $\S 213.2 \mathrm{cmt} .1$ at 358 n.2 (citing Alfred C. Kinsey, SeXual Behavior IN the Human Female (1953)); 359 n.6 (same); § 213.6 note 3 at 437 n.26 (same).

44 Id. $\$ 213.2 \mathrm{cmt}$. 2 at $363 \mathrm{n} .27$ (citing ALFRED C. KINSEY ET AL., SEXUAL BEHAVIOR IN THE HUMAN MALE (1948)); $§ 213.6$ note 3 at $437 \mathrm{nn} .26$ \& 27 (same).

45 Id. $\$ 213.2 \mathrm{cmt}$. 2 at $363 \mathrm{n} .26$ (citing Alex COMFORT, THE JOY OF SEX: A CORDON BleU GUIDE TO LOVEMAKING (1972)).

46 Id. (citing David R. Reuben, Everything You Always Wanted to Know About Sex, But WERE AFrAID TO ASK (1970)). 
Marriage (1955) ${ }^{47}$ and The Pleasure Bond $(1970) .{ }^{48}$.This groundbreaking literature is now, for the most part, ${ }^{49}$ the stuff of history. In some cases, it is also empirically questionable, such as Kinsey's research, which had a particularly strong impact on the Code's reporters. ${ }^{50}$ One can imagine future generations of law professors and students who simply will not be able to recognize these book titles or relate to their contents, despite the worthy rationales for their use.

Other books, such as Menachem Amir's Patterns in Forcible Rape, ${ }^{51}$ are cited throughout the Commentaries as a reliable source of rape statistics. Yet, Amir's data are over four decades old. Some findings have not stood the test of time-for example, Amir's conclusion that nineteen percent of all rapes were "victimprecipitated" based upon a very broad, and unprecedented, definition of what "precipitation" means. ${ }^{52}$ There are numerous, more methodologically sound studies that can now replace these data for authority.

\section{SOME OF THE CODE'S FeAtURES THAT FAIL THE TEST OF TIME}

Additional, perhaps more widely discussed, aspects of the Code's sexual offense provisions also show their age. Some of these aspects are listed below.

\section{A. The Marital Immunity Rule}

The marital immunity rule - specifying that a husband could not legally rape his wife-has been narrowed or abolished in nearly all states. The Code, however, adopted a partial marital exemption; generally, nonconsensual intercourse with a spouse is not rape. ${ }^{53}$ But, the Commentaries recognized that the times were changing and that the Code could too:

47 Id. at n.28. (citing Oliver M. ButTerfield, SeXual HaRMONY IN MaRRiage (1953)).

48 Id. (citing William H. Masters et al., The Pleasure Bond: A New Look at Sexuality and COMMITMENT (1970)).

49 Of course, these comments are not to suggest that this literature is unworthy or unimportant. Rather, the literature is historical and not necessarily representative of current attitudes.

50 See Allyn, supra note 9, at 407-28.

5I Menachem Amir, Patterns in Forcible RaPe (1971).

52 Id. at 266. Amir's definition of "victim precipitation" would not be found acceptable today.

The term "victim precipitation" describes those rape situations in which the victim actually, or so it was deemed, agreed to sexual relations but retracted before the actual act or did not react strongly enough when the suggestion was made by the offender(s). The term applies also to cases in risky situations marred with sexuality, especially when she [the victim] uses what could be interpreted as indecency of language and gestures, or constitutes what could be taken as an invitation to sexual relations.

Id.

53 Model Penal Code 1980, supra note $2, \S 213.6(2)$ at 411. 
Extension of criminal sanctions to reach coercive relations between husband and wife is a common feature of feminist proposals for reforming the law of rape, and appears to have been accepted in a number of recent revisions. This activity should prompt a fresh look at the advisability of the spousal exclusion. ${ }^{54}$

\section{B. The Corroboration Requirement}

The corroboration requirement-mandating that no person will be convicted of rape upon the uncorroborated testimony of the alleged victim ${ }^{55}$ - has been heavily criticized and is now followed by only a few states. ${ }^{56}$ Yet, the Code still retains the requirement. Most likely, the Code's reporters thought that it would have been difficult to eliminate such a rule in 1962 since it was then followed by the majority of states. ${ }^{57}$ Regardless, the Commentaries acknowledged the controversy surrounding the rule in the 1970s and stressed that attitudes toward the doctrine were increasingly in a state of flux. ${ }^{58}$

\section{The Prompt Complaint Rule}

Under the Code's prompt complaint rule, a prosecution for a sexual offense is barred if a competent adult complainant fails to notify a law enforcement agency of the offense within three months of its occurrence. ${ }^{59}$ By today's standards, this requirement is highly dubious and the Code's reasons for it are troubling. The Code's rule - "an innovation in Anglo-American law" - is also one of the rare times the Code made a conservative deviation from legal trends. For example, the Commentaries acknowledged that "[a]t the time the Model Penal Code was drafted, failure to make a prompt complaint did not bar prosecution for a sex offense in any jurisdiction, but evidence of prompt notification to the authorities was admissible to rebut a suggestion of fabrication by the complainant."

The Commentaries' reasons for the prompt complaint rule hark back to a time when there was a strong presumption that a substantial number of female complainants would invent their charges for a wide range of reasons: "unwanted pregnancy," "bitterness at a relationship gone sour [that] might convert a willing participant in sexual relations into a vindictive complainant," or "the opportunity for

54 Id. $\S 213.1 \mathrm{cmt} .6$ at 343 .

55 Model Penal CODE 1980, supra note 2, $\$ 213.6(5)$ at 412.

56 Joshua Dressler, Understanding Criminal Law 598 (3d ed. 2001).

57 Model Penal Code 1980, supra note 2, $\$ 213.6 \mathrm{cmt}$. 6 at 423.

58 Id. at 422 (recognizing that "[s]pecial rules of this sort have excited considerable controversy in recent years and have become targets of bitter criticism by feminist reformers and their allies").

59 Model Penal Code 1980, supra note 2, § 213.6(4) at 412.

$60 \quad$ Id. cmt. 5 at 421.

61 Id. at 420. 
blackmailing another by threatening to bring a criminal charge of sexual aggression"-an "objective" that the Commentaries considered to be "especially critical for those offenses involving consensual relations." ${ }^{.62}$ For example, "[t]he parents of an underage girl who has engaged in intercourse with an older male ... may forego public prosecution, which does nothing to enhance the reputation of their daughter, in favor of private gain." ${ }^{63}$ As the Commentaries explained, "[r]equiring complaint within three months of learning of such an event reduces the ability of such persons to demand continuing payment for silence."

The Commentaries provide no support whatsoever for any of these presumptions or speculations. By today's standards, they sound outrageous. Yet, such views were entirely consistent with American norms and culture at the time they were expressed. While the strong social presumption of female "sexual blackmail" took full force in the beginning decades of the twentieth century, ${ }^{65}$ it was still widely accepted when the Code's provisions and Commentaries were being drafted.

\section{The Sexually Promiscuous Complainant Rule}

Under some subsections of the "corruption of minors and sexual assault" provisions, the Code provides a defense "that the alleged victim had, prior to the time of the offense charged, engaged promiscuously in sexual relations with others." ${ }^{66}$ The Commentaries explain that "proof of prior sexual promiscuity rebuts the presumption of naiveté and inexperience that supports the imposition of criminal liability."67 A primary example is "the underage prostitute" for whom "imposition of felony sanctions designed to protect the young and inexperienced seems manifestly inappropriate." ${ }^{68}$ The Commentaries conceded, however, that "[m]ost of the recently drafted codes and proposals have not included a similar defense."

While the Code was consistent with the social times, the Commentaries acknowledged that the sexually promiscuous complainant rule was not up with the legal times. The rule certainly contravenes what we know now.

\footnotetext{
62 Id. at 421 .

63 Id.

64 Id.

65 For an excellent overview of these developments, see generally ANGUS MCLAREN, SEXUAL BLACKMAIL: A MODERN HISTORY (2002).

66 Model Penal CODE 1980, supra note $2, \S 213.6(3)$ at 412 . The Commentaries point out that this provision does not apply to the MPC "offenses defined in terms of force or imposition." Id. § 213.6 cmt. 4 at 419.

${ }^{67} I d . \S 213.6 \mathrm{cmt} .4$ at 420.
${ }_{68}$ Id.
${ }_{69} I d$.
} 


\section{E. Types of Sexual Activity and Influences on Rape}

The Code's sexual offense provisions inherited their era. For example, the sexual abuse of young children was not nearly as widely recognized as it is today, ${ }^{70}$ marital and nonmarital sexual relationships were far more sexually conservative; the concept of "date rape" was just starting to be introduced, HIV/AIDS was not an issue, casual Internet meetings among people did not exist, and the use of date rape drugs was rare and less serious. Likewise, there was far less awareness of more diverse forms of sexual activity, such as sadomasochistic sex, or other means of penetration which the Code was just beginning to acknowledge, for example, "digital or mechanical penetration." of issues, as well as recent developments such as whether or not a state should recognize post-penetrative rape. ${ }^{72}$

\section{F. Psychological and Cultural Attitudes Toward Sex}

The Code's provisions were influenced by the psychoanalytic age of their origins - the 1950s and $1960 \mathrm{~s}^{73}$ - while the Commentaries also reflected the cultural landscape of the 1960s and 1970s. Morris Ploscowe, one of the Code's most renowned reporters, became a symbol of some of the more sexist attitudes spanning these decades by virtue of his writings and proclamations. Although Ploscowe asserted a number of inflammatory remarks, perhaps his most remembered are those pertaining to the reasons for having a corroboration requirement for rape (as opposed to other crimes). According to Ploscowe, corroboration was important because when it comes to rape, "ladies lie., ${ }^{, 74}$ Ploscowe never successfully shed the repercussions of making this statement, which was even highlighted in his New York Times obituary. ${ }^{75}$

70 For example, there is only one footnote on the subject of sexual abuse of young children in the Commentaries and that footnote cites only to two books that are each a half-century old. $I d . \S 213.1 \mathrm{cmt}$. 6 at 328 n. 149 (citing Benjamin KaRPMAN, The SeXual OfFender AND His Offenses (1954); MorRIS Ploscowe, Sex and the Law (1951)).

71 Id. cmt. 8 at 346.

72 See In re John Z, 60 P.3d 183, 184 (Cal. 2003) (holding that a "withdrawal of consent [during intercourse] effectively nullifies any earlier consent and subjects the male to forcible rape charges if he persists in what has become nonconsensual intercourse").

73 Deborah W. Denno, Crime and Consciousness: Science and Involuntary Acts, 87 MINN. L. REV. 269, 294-308 (2002).

74 William M. Freeman, Ex-Magistrate Ploscowe Dies; Criminal-Law Expert Was 71, N.Y. TIMES, Sept. 22, 1975, at 36. There was a great outcry to Ploscowe's statement. See, e.g., Lesley Oelsner, "Because Ladies Lie," N.Y. TimES, May 14, 1972, at E5 (noting that "there appears to be a lot of opinion-filled literature, but little statistical fact" supporting the proposition that people lie more about rape than other crimes, such as robbery). following:

75 Freeman, supra note 74, at 36. Morris Ploscowe's quarter-page obituary contained the

In 1972, discussing legislation on rape, [Ploscowe] observed that the victim's word was sufficient for a prosecutor to make out a prima facie case, enough to 


\section{G. Psychological and Cultural Attitudes Toward Sexual Assault}

The language the Commentaries use is often noticeably antiquated even when the Code's recommendations seem sensible. A particularly startling illustration is the Commentaries' attempt to distinguish sexual assault, ${ }^{76}$ an "invasion of personal dignity," from legally acceptable personal contact, such as a "casual expression of affection or approval." who pats his players on the bottom is merely fulfilling a ritual of congratulation. Even if such contact proves unwelcome to the recipient, the actor may not be held liable for this offense." ${ }^{78}$ But when the Commentaries go further and attempt to differentiate acceptable from unacceptable uses of tactile contact, they rely on an archaic hypothetical involving an "affectionate" elderly man and a young woman. The Commentaries have this to say:

Premising liability on a kiss or hug would place too much weight on the ability of the judge or jury to distinguish affection from passion. ${ }^{79}$ The elderly gentleman who kisses a pretty girl or pats her on the bottom should not be subjected to prosecution as a sex offender on the theory that he was securing sexual gratification by such conduct. ... This provision therefore requires some more demonstrative act ... ${ }^{80}$

This example illuminates how the language of the Commentaries is tainted by the time in which they were written. These colloquial remarks, which were perhaps customary decades ago, seem entirely inappropriate to us now. They also show that the criminal law must move forward.

\section{CONCLUSION}

This essay examined the Model Penal Code's sexual offense provisions and Commentaries to support my recommendation that the Code's sexual offense provisions be pulled and replaced. Of course, in such limited space, my purpose was not to propose how this should be done but simply why. The best argument for change comes from simply considering what the Code's provisions, and their Commentaries, say.

\footnotetext{
take to a jury on assault, robbery, fraud and other crimes, but it was not enough for the crime of rape, because, he said, "ladies lie." 
Some may think that, with the diversity of today's culture, it may be too difficult to reach a consensus on new model sexual offense provisions. I do not think that's the case, given the controversies that existed when the initial provisions were created. The Code's reporters have already addressed some of the most arduous questions. They have also established a firm foundation of principles so reforms can remain "real" ${ }^{, 81}$ and not radical. ${ }^{82}$ This is not to suggest that the task of revising the Code's sexual offense provisions will be easy. I'm sure the first set of reporters encountered enormous hurdles. Yet, those reporters serve as an inspiration for us all. Hard jobs can get done.

81 See Lynch, supra note 1, at 236-39.

82 For a pointed discussion about the problems stemming from the somewhat more radical changes from rape law precedent, see Joshua Dressler, Where We Have Been, and Where We Might be Going: Some Cautionary Reflections on Rape Law Reform, 46 CLEV. ST. L. REV. 409 (1998). 